\title{
Is hepatic lipid metabolism of beef cattle influenced by breed and dietary silage level?
}

\author{
Ana Sofia Henriques da Costaํ', Rui José Branquinho Bessa', Virgínia Maria Rico Pires ${ }^{1}$, Eva Alves Rolo ${ }^{1}$, \\ Rui Manuel Amaro Pinto ${ }^{2}$, Carlos Mendes Godinho Andrade Fontes ${ }^{1}$ and José António Mestre Prates ${ }^{1 *}$
}

\begin{abstract}
Background: In ruminants, unsaturated dietary fatty acids are biohydrogenated in the rumen and are further metabolised in various tissues, including liver, which has an important role in lipid and lipoprotein metabolism. Therefore, manipulation of muscle fatty acid composition should take into account liver metabolism. In the present study, the influence of breed and diet on liver lipid composition and gene expression was investigated in order to clarify the role of this organ in the lipid metabolism of ruminants. Forty purebred young bulls from two phylogenetically distant autochthonous cattle breeds, Alentejana and Barrosã, were assigned to two different diets (low vs. high silage) and slaughtered at 18 months of age. Liver fatty acid composition, mRNA levels of enzymes and transcription factors involved in lipid metabolism, as well as the plasma lipid profile, were assessed.

Results: In spite of similar plasma non-esterified fatty acids levels, liver triacylglycerols content was higher in Barrosã than in Alentejana bulls. Moreover, the fatty acid composition of liver was clearly distinct from the remaining tissues involved in fatty acid metabolism of ruminants, as shown by Principal Components Analysis. The hepatic tissue is particularly rich in a-linolenic acid and their products of desaturation and elongation. Results indicate that DGAT1, ELOVL2, FADS1 and FADS2 genes influence the fatty acid composition of the liver the most. Moreover, genes such as DGAT1 and ELOVL2 appear to be more sensitive to genetic background than to dietary manipulation, whereas genes encoding for desaturases, such as FADS1, appear to be modulated by dietary silage level.

Conclusions: Our results indicate that liver plays an important role in the biosynthesis of n-3 LC-PUFA. It is also suggested that dietary silage level influences the hepatic fatty acid metabolism in a breed-dependent manner, through changes in the expression of genes encoding for enzymes associated with the desaturation and elongation pathway. The importance of devising custom-made feeding strategies taking into account the genetic background is, therefore, stressed by the results from this experiment.
\end{abstract}

Keywords: Liver, Beef cattle, Fatty acids, Gene expression

\section{Background}

Despite the predominant role of adipose tissue in ruminant's de novo fatty acid synthesis, the liver also plays an important role in ruminant lipid metabolism [1]. This organ carries out central metabolic functions in various aspects of lipid and lipoprotein metabolism, such as uptake, oxidation and metabolic conversion of non-esterified

\footnotetext{
*Correspondence: japrates@fmv.utl.pt

'CIISA, Faculdade de Medicina Veterinária, Universidade de Lisboa, Av. da Universidade Técnica, Pólo Universitário do Alto da Ajuda, 1300-477 Lisboa, Portugal

Full list of author information is available at the end of the article
}

fatty acids (NEFA), synthesis of cholesterol and phospholipids, and formation and secretion of specific classes of lipoproteins [1]. The ruminants' liver removes little or no triacylglycerols from blood lipoproteins [2]. Uptake of NEFA is the predominant route by which fatty acids are supplied to the liver [3] and, thus, plasma lipid fatty acid composition should influence the liver fatty acid metabolism and composition [2]. Consequently, the regulation of these liver metabolic pathways may affect fatty acid deposition into lipids of ruminant products [4].

Interest in n-3 long-chain polyunsaturated fatty acids (n-3 LC-PUFA) has increased since it was found that

\section{Biomed Central}


their consumption in most Western populations, particularly those of eicosapentaenoic acid (EPA) and docosahexaenoic acid (DHA), is sub-optimal for protection against the most prevalent chronic diseases [5]. In grazing ruminants, $\alpha$-linolenic acid content of muscles increases with the concomitant increase in n-3 LC-PUFA contents [6]. In contrast, although the addition of linseed to ruminant diets $[7,8]$ increases the $\alpha$-linolenic acid content of muscles, the n-3 LC-PUFA levels stay unchanged or increase only slightly. In fact, Bessa et al. [9] reported that lucerne supplementation with linseed oil promoted an increase in ALA coupled with a decrease in n-3 LC-PUFA in lambs, when compared to the control diet (lucerne only). According to the authors, these results suggest the inhibition of $\alpha$-linolenic acid metabolism by vegetable oils rich in n-3 PUFA. Therefore, the abundance of n-3 LCPUFA in ruminants' tissues appears to depend not only on dietary n-3 PUFA but also on their endogenous synthesis via elongation and desaturation of dietary n-3 PUFA.

The biosynthesis of DHA from $\alpha$-linolenic acid is performed through alternating steps of desaturation and elongation, followed by a final step of peroxisomal $\beta$ oxidation. This metabolic pathway involves two desaturases ( $\Delta 5$ and $\Delta 6$ desaturases), two elongases (elongases 2 and 5) and enzymes of the peroxisomal $\beta$-oxidation [10]. The activity of these enzymes is currently regarded as potential limiting steps in this biosynthesis, possibly in a tissue dependent manner. However, recent studies addressed the role of the liver in ruminants' lipid metabolism, either using in vitro experiments [4] or in vivo assays [11]. These experiments raised some interesting clues on hepatic lipid metabolism, namely the extensive catabolism of $\alpha$-linolenic acid [4] and the low or negligible expression level of genes encoding for enzymes of fatty acid desaturation and elongation [11]. Therefore, the role of bovine liver, as a central metabolic organ, on lipid metabolism remains to be elucidated.

An experiment with 40 young bulls from two genetically diverse beef cattle breeds, Alentejana and Barrosã, fed either high (70\% silage/30\% concentrate) or low (30\% silage/70\% concentrate) silage diets was carried out by our group to study the breed and diet effects on lipid metabolism. Previous reports from this experiment $[12,13]$ showed that these breeds have a distinct response to the variation in dietary silage level, as assessed by the fatty acid composition and the mRNA levels of key lipogenic factors of the main fat depots and muscle. Bearing this in mind, as well as the studies by Gruffat et al. [4] and Cherfaoui et al. [11], we aimed to investigate whether the same breedspecific response to dietary silage level would be observed in the liver. For this purpose, the detailed fatty acid composition of liver from Alentejana and Barrosã bulls, in parallel to their mRNA levels of key genes associated with lipid metabolism, were determined.

\section{Results}

\section{Body composition and plasma metabolites}

The body composition parameters and plasma metabolites are depicted in Table 1. Initial and slaughter weights were higher for Alentejana when compared to Barrosã bulls $(P<0.001)$. Liver total lipids content was higher in Barrosã than in Alentejana bulls $(P<0.01)$. Both aminotransferases, AST and ALT, were higher in Alentejana than in Barrosã bulls $(P<0.05)$. The high silage fed bulls had higher ALT plasma levels than those fed the low silage diet $(P<0.05)$. Liver weight, when expressed relatively to carcass weight, was similar across experimental groups $(P>0.05)$. All plasma lipid parameters analysed were similar, regardless of breed or diet $(P>0.05)$. The ALP plasma levels were not influenced by breed or dietary silage level $(P>0.05)$.

\section{Total lipids and fatty acid composition analysis}

The detailed fatty acid composition of the subcutaneous and mesenteric adipose tissues, as well as that of longissimus lumborum muscle, was published in companion papers (Costa et al. [12,13], respectively). The liver total fatty acid content and composition is depicted in Table 2. Total fatty acids content was higher in the liver from Barrosã when compared to Alentejana bulls $(P<0.01)$. There were breed determined differences in 5 of the 31 identified fatty acids, but diet had the most important role over the individual fatty acid percentages. Alentejana bulls showed consistently lower percentages of 18:1 $t 11, c 9, t 11$-CLA, 20:3n-9, 20:1c11 and TFA, when compared to the Barrosã bulls, but higher 20:4n-6 and 22:6n-3 percentages $(P<0.05)$. The high silage diet promoted the deposition of $14: 1 c 9,15: 0,18: 3 n-3,20: 5 n-3$, 22:5n-3, 22:6n-3 and 23:0 when compared to the low silage diet $(P<0.05)$. In contrast, the percentages of $18: 1$ $t 6-t 8,18: 1 t 9,18: 1 t 10,18.1 t 12,18: 1 c 11,18: 1 c 13$ and 22:4n-6 were higher in the low silage fed bulls, when compared to those fed the high silage diet $(P<0.05)$. Total n-3 PUFA and n-3 LC-PUFA were higher in the liver from the high silage fed bulls, when compared to those fed the low silage diet $(P<0.001)$. The Barrosã bulls fed the low silage had the lowest total PUFA and n-6 PUFA percentages (breed $\times$ diet, $P<0.05$ ).

\section{Gene expression analysis}

Results from the gene expression analysis are shown in Figure 1. Breed influenced the mRNA levels of both DGAT1 and ELOVL2, with higher values for the Barrosã when compared to Alentejana bulls $(P<0.05$ and $P<0.01$, respectively). In turn, the expression levels of FADS1 were higher in low silage in comparison to high silage fed bulls $(P<0.05)$. Similarly, the low silage diet tended to promote higher FADS2 mRNA expression levels than the high silage diet, but only in the Alentejana bulls (breed $\times$ diet 
Table 1 Body composition parameters and plasma metabolites

\begin{tabular}{|c|c|c|c|c|c|c|c|}
\hline & \multicolumn{2}{|c|}{ Alentejana } & \multicolumn{2}{|c|}{ Barrosã } & \multicolumn{3}{|c|}{$P$ value } \\
\hline & HS & LS & HS & LS & Breed & Diet & Breed $\times$ diet \\
\hline \multicolumn{8}{|l|}{ Growth and body composition } \\
\hline Initial weight $(\mathrm{kg})$ & $267 \pm 16.8$ & $264 \pm 13.9$ & $210 \pm 4.5$ & $214 \pm 5.9$ & $<0.001$ & 0.954 & 0.792 \\
\hline Slaughter weight $(\mathrm{kg})$ & $622 \pm 17.7$ & $636 \pm 29.7$ & $457 \pm 8.9$ & $497 \pm 23.0$ & $<0.001$ & 0.207 & 0.542 \\
\hline Normalized liver weight (\% carcass weight) & $2.08 \pm 0.061$ & $1.95 \pm 0.128$ & $2.08 \pm 0.052$ & $2.01 \pm 0.063$ & 0.701 & 0.226 & 0.662 \\
\hline Hepatic total lipids (mg/100 g liver) & $2.99 \pm 0.114$ & $2.96 \pm 0.079$ & $3.29 \pm 0.095$ & $3.43 \pm 0.146$ & 0.002 & 0.620 & 0.448 \\
\hline \multicolumn{8}{|l|}{ Plasma lipid profile } \\
\hline Total cholesterol (mg/l) & $863 \pm 49.5$ & $884 \pm 77.3$ & $892 \pm 46.6$ & $837 \pm 103.5$ & 0.903 & 0.818 & 0.607 \\
\hline HDL-cholesterol (mg/l) & $408 \pm 17.5$ & $393 \pm 25.7$ & $366 \pm 14.4$ & $353 \pm 41.0$ & 0.139 & 0.606 & 0.971 \\
\hline LDL-cholesterol (mg/l) & $83.1 \pm 6.41$ & $84.9 \pm 12.70$ & $78.0 \pm 6.46$ & $84.0 \pm 9.45$ & 0.745 & 0.672 & 0.820 \\
\hline VLDL-cholesterol (mg/l) & $35.0 \pm 4.59$ & $35.2 \pm 2.07$ & $34.0 \pm 2.42$ & $36.8 \pm 2.98$ & 0.925 & 0.640 & 0.685 \\
\hline Triacylglycerols $^{\dagger}(\mathrm{mg} / \mathrm{l})$ & $175 \pm 23.0$ & $176 \pm 10.3$ & $170 \pm 12.1$ & $184 \pm 14.9$ & 0.925 & 0.640 & 0.685 \\
\hline Non esterified fatty acids (mM) & $0.06 \pm 0.02$ & $0.06 \pm 0.01$ & $0.06 \pm 0.02$ & $0.03 \pm 0.01$ & 0.219 & 0.250 & 0.447 \\
\hline Total lipids (mg/l) & $3401 \pm 113.0$ & $3444 \pm 160.0$ & $3454 \pm 96.6$ & $3358 \pm 209.3$ & 0.914 & 0.862 & 0.650 \\
\hline \multicolumn{8}{|l|}{ Plasma hepatic markers } \\
\hline AST (U/I) & $83.0 \pm 3.60$ & $99.7 \pm 15.50$ & $71.3 \pm 3.24$ & $67.2 \pm 3.74$ & 0.021 & 0.464 & 0.236 \\
\hline $\mathrm{ALT}(\mathrm{U} / \mathrm{I})$ & $30.4 \pm 1.83$ & $28.9 \pm 3.02$ & $26.5 \pm 2.21$ & $18.1 \pm 1.69$ & 0.003 & 0.036 & 0.136 \\
\hline ALP (U/I) & $199 \pm 37.2$ & $173 \pm 25.8$ & $218 \pm 25.1$ & $200 \pm 25.7$ & 0.430 & 0.461 & 0.902 \\
\hline
\end{tabular}

${ }^{\dagger}$ Published in Costa et al. [12].

$P=0.072$ ). In addition, Alentejana bulls tended to have the highest PPARA gene expression levels when fed the low silage diet, whereas the inverse trend was found for Barrosã bulls (breed $\times$ diet, $P=0.086$ ). Neither breed nor diet influenced the expression of CPT1A, ELOVL5, FASN, INSR, SCD and SREBF1 genes $(P>0.05)$.

\section{Correlation analysis}

The correlation analysis between genes and fatty acid percentages is depicted in Table 3. The FADS1 and FADS2 genes were shown as the most associated with fatty acid composition, along with CPT1A and ELOVL5. Positive correlations were found for the CPT1A expression level and the 14:0 $(r=0.56)$, and 16:0 $(r=0.60)$ percentages. The CPT1A gene was also positively correlated with the percentages of $16: 1 c 9 \quad(r=0.47)$, $17: 1 c 9(r=0.31)$, and $18: 1 c 9(r=0.42)$. Negative correlations were observed between the CPT1A gene and $20: 2 \mathrm{n}-6(r=-0.59)$ and $22: 4 \mathrm{n}-6(r=-0.32)$ fatty acids.

The expression levels of DGAT1 showed a moderate positive correlation with the 20:3n-9 percentage $(r=0.44)$. The percentages of 16:0 $(r=0.44), 16: 1 c 9(r=0.37)$ and 20:3n-9 $(r=0.40)$ showed positive correlations with the ELOVL2 gene expression levels. A negative correlation was observed between ELOVL2 mRNA level and the 17:0 percentage $(r=-0.37)$. Expression of the ELOVL5 gene was positively correlated with the percentages of 14:0 $(r=0.40), 16: 0(r=0.60), 16: 1 c 9 \quad(r=0.51), 17: 1 c 9$ $(r=0.39)$ and 18:1c9 $(r=0.50)$. In addition, there were
ELOVL5 mRNA levels were negatively correlated with 18:0 $(r=-0.40), \quad 18: 1 c 9 \quad(r=0.33), \quad 18: 2 \mathrm{n}-6 \quad(r=-0.32)$ and 20:2n-6 $(r=-0.46)$.

The FADS1 mRNA levels were positively associated with 14:0 $(r=0.39), 16: 0(r=0.42), 16: 1 c 7(r=0.48), 16: 1 c 9$ $(r=0.38), 17: 1 c 9 \quad(r=0.33), 18: 1 c 9 \quad(r=0.38), 18: 1 c 11$ $(r=0.51), 18: 1 c 13(r=0.48), 20: 0(r=0.48), 20: 3 n-6(r=0.50)$ and 22:4n-6 $(r=0.72)$ fatty acids. In addition, FADS1 showed negative correlations with 18:0 $(r=-0.41), 18: 2 \mathrm{n}-6$ $(r=-0.53), 18: 3 \mathrm{n}-3(r=-0.46)$ and $20: 2 \mathrm{n}-6(r=-0.34)$. The relative expression of FADS2 was positively correlated with the percentages of 14:0 $(r=0.34), 16: 1 c 7 \quad(r=0.44)$, 18:1 $t 9(r=0.40), 18: 1 c 11(r=0.40), 18: 1 c 13(r=0.39), 20: 0$ $(r=0.68), 20: 1 c 11$ ( $r=0.38), 20: 3 \mathrm{n}-6(r=0.67)$ and 22:4n-6 $(r=0.70)$. Negative correlations were found between the FADS2 and 18:n-6 $(r=-0.52)$ and 18:3n-3 $(r=-0.50)$ fatty acids percentages. The $14: 1 c 9$ fatty acid was positively correlated with the FASN gene expression levels $(r=0.42)$.

The INSR relative mRNA levels were positively correlated with the 14:0 $(r=0.32), 20: 1 c 11 \quad(r=0.32), 20: 3 n-6$ $(r=0.35), 22: 5 \mathrm{n}-3 \quad(r=0.32)$ percentages, but negatively associated with the 18:2n-6 $(r=-0.33)$ and $20: 2 n-6$ percentages $(r=-0.38)$. The PPARA mRNA levels showed positive correlations with 20:1c11 $(r=0.38)$ and 20:4n-6 $(r=0.34)$ fatty acids percentages.

\section{Principal components analysis}

A PCA of the fatty acid composition of muscle, subcutaneous adipose tissue, mesenteric adipose tissue and liver 
Table 2 Total fatty acids and fatty acid composition of liver from Alentejana and Barrosã bulls fed high or low silage diets $^{1-3}$

\begin{tabular}{|c|c|c|c|c|c|c|c|c|c|c|c|}
\hline & \multicolumn{4}{|c|}{ Alentejana } & \multicolumn{4}{|c|}{ Barrosã } & \multicolumn{3}{|c|}{$P$ value } \\
\hline & HS & SE & LS & $\mathrm{SE}$ & HS & SE & LS & SE & Breed & Diet & Breed $\times$ Diet \\
\hline Total fatty acids & 1.98 & 0.02 & 1.98 & 0.02 & 2.05 & 0.02 & 2.04 & 0.03 & 0.007 & 0.816 & 0.858 \\
\hline \multicolumn{12}{|l|}{ Fatty acids } \\
\hline $14: 0$ & 0.49 & 0.04 & 0.46 & 0.05 & 0.51 & 0.05 & 0.58 & 0.07 & 0.204 & 0.701 & 0.425 \\
\hline $14: 1 c 9$ & 0.29 & 0.02 & 0.20 & 0.05 & 0.28 & 0.02 & 0.19 & 0.02 & 0.795 & 0.008 & 0.852 \\
\hline $15: 0$ & 0.23 & 0.01 & 0.18 & 0.02 & 0.22 & 0.02 & 0.21 & 0.01 & 0.573 & 0.039 & 0.229 \\
\hline $16: 0$ & 9.59 & 0.45 & 9.43 & 0.55 & 9.42 & 0.32 & 11.35 & 0.90 & 0.154 & 0.150 & 0.091 \\
\hline $16: 1 c 7$ & 0.23 & 0.01 & 0.25 & 0.02 & 0.24 & 0.01 & 0.30 & 0.05 & 0.266 & 0.192 & 0.494 \\
\hline $16: 1 c 9$ & 0.53 & 0.07 & 0.54 & 0.07 & 0.55 & 0.05 & 0.78 & 0.12 & 0.126 & 0.161 & 0.163 \\
\hline $17: 0$ & 1.08 & 0.02 & 1.05 & 0.05 & 1.07 & 0.05 & 0.96 & 0.04 & 0.244 & 0.084 & 0.311 \\
\hline $17: 1 c 9$ & 0.31 & 0.03 & 0.29 & 0.02 & 0.29 & 0.01 & 0.31 & 0.03 & 0.910 & 0.907 & 0.555 \\
\hline $18: 0$ & 33.66 & 0.49 & 33.57 & 0.96 & 33.24 & 0.51 & 33.16 & 1.09 & 0.614 & 0.919 & 0.997 \\
\hline $18: 1 t 6-t 8$ & 0.05 & 0.00 & 0.07 & 0.01 & 0.05 & 0.00 & 0.06 & 0.00 & 0.647 & 0.010 & 0.922 \\
\hline $18: 1$ t9 & 0.06 & 0.00 & 0.08 & 0.00 & 0.06 & 0.00 & 0.09 & 0.01 & 0.333 & $<0.001$ & 0.382 \\
\hline $18: 1 t 10$ & 0.07 & 0.00 & 0.16 & 0.02 & 0.07 & 0.00 & 0.11 & 0.01 & 0.068 & $<0.001$ & 0.060 \\
\hline 18:1 t11 & 0.86 & 0.07 & 0.97 & 0.09 & 1.09 & 0.11 & 1.11 & 0.07 & 0.049 & 0.484 & 0.644 \\
\hline $18: 1 t 12$ & 0.37 & 0.02 & 0.43 & 0.03 & 0.37 & 0.01 & 0.44 & 0.03 & 0.794 & 0.019 & 0.792 \\
\hline $18: 1 c 9$ & 11.42 & 0.69 & 10.86 & 0.52 & 11.11 & 0.30 & 12.91 & 0.89 & 0.186 & 0.345 & 0.078 \\
\hline 18:1C11 & 1.58 & 0.06 & 1.78 & 0.13 & 1.55 & 0.05 & 1.99 & 0.20 & 0.516 & 0.022 & 0.370 \\
\hline $18: 1 c 12$ & 0.28 & 0.02 & 0.27 & 0.02 & 0.25 & 0.02 & 0.31 & 0.03 & 0.775 & 0.224 & 0.106 \\
\hline $18: 1 c 13$ & 0.10 & 0.01 & 0.13 & 0.01 & 0.10 & 0.01 & 0.13 & 0.01 & 0.964 & 0.010 & 0.792 \\
\hline $18: 1 t 16+c 14$ & 0.10 & 0.01 & 0.10 & 0.01 & 0.09 & 0.00 & 0.11 & 0.01 & 0.873 & 0.567 & 0.197 \\
\hline $18: 2 n-6$ & 16.16 & 0.87 & 17.08 & 1.17 & 16.32 & 0.51 & 14.67 & 1.02 & 0.235 & 0.694 & 0.174 \\
\hline $18: 3 n-3$ & 1.24 & 0.08 & 0.80 & 0.06 & 1.21 & 0.05 & 0.73 & 0.06 & 0.465 & $<0.001$ & 0.796 \\
\hline CLA (c9t11) & 0.37 & 0.02 & 0.28 & 0.03 & 0.48 & 0.04 & 0.44 & 0.06 & 0.001 & 0.098 & 0.453 \\
\hline $20: 0$ & 0.12 & 0.01 & 0.13 & 0.02 & 0.13 & 0.01 & 0.14 & 0.01 & 0.389 & 0.363 & 0.859 \\
\hline 20:1c11 & 0.09 & 0.01 & 0.11 & 0.01 & 0.13 & 0.01 & 0.12 & 0.01 & 0.010 & 0.466 & 0.273 \\
\hline $20: 2 n-6$ & 0.30 & 0.03 & 0.30 & 0.04 & 0.30 & 0.02 & 0.25 & 0.03 & 0.362 & 0.446 & 0.312 \\
\hline $20: 3 n-9$ & 0.39 & 0.03 & 0.33 & 0.03 & 0.77 & 0.04 & 0.78 & 0.04 & $<0.001$ & 0.462 & 0.336 \\
\hline $20: 3 n-6$ & 2.43 & 0.21 & 2.76 & 0.29 & 2.54 & 0.25 & 2.64 & 0.25 & 0.982 & 0.383 & 0.636 \\
\hline $20: 4 n-6$ & 9.24 & 0.18 & 9.39 & 0.23 & 9.00 & 0.19 & 7.96 & 0.56 & 0.022 & 0.196 & 0.088 \\
\hline $20: 5 n-3$ & 0.42 & 0.02 & 0.25 & 0.02 & 0.37 & 0.02 & 0.26 & 0.02 & 0.412 & $<0.001$ & 0.279 \\
\hline $22: 4 n-6$ & 1.64 & 0.10 & 2.26 & 0.21 & 1.86 & 0.12 & 1.97 & 0.22 & 0.839 & 0.042 & 0.145 \\
\hline $22: 5 n-3$ & 2.93 & 0.14 & 2.60 & 0.14 & 3.03 & 0.07 & 2.11 & 0.21 & 0.204 & $<0.001$ & 0.056 \\
\hline $22: 6 n-3$ & 1.28 & 0.10 & 0.79 & 0.06 & 1.06 & 0.05 & 0.70 & 0.08 & 0.044 & $<0.001$ & 0.393 \\
\hline 23:0 & 0.21 & 0.04 & 0.13 & 0.02 & 0.22 & 0.02 & 0.16 & 0.02 & 0.494 & 0.009 & 0.753 \\
\hline Other $^{4}$ & 1.90 & 0.06 & 1.99 & 0.10 & 2.01 & 0.08 & 2.01 & 0.10 & 0.435 & 0.604 & 0.606 \\
\hline \multicolumn{12}{|l|}{ Partial sums } \\
\hline SFA & 45.38 & 0.24 & 44.95 & 0.63 & 44.82 & 0.25 & 46.55 & 0.96 & 0.393 & 0.292 & 0.087 \\
\hline MUFA & 14.83 & 0.83 & 14.43 & 0.75 & 14.50 & 0.38 & 17.03 & 1.28 & 0.205 & 0.231 & 0.106 \\
\hline TFA & 1.89 & 0.11 & 2.07 & 0.15 & 2.21 & 0.16 & 2.36 & 0.12 & 0.033 & 0.233 & 0.896 \\
\hline PUFA & $36.01^{b}$ & 0.83 & $36.56^{b}$ & 0.85 & $36.46^{b}$ & 0.37 & $32.05^{a}$ & 1.55 & 0.055 & 0.066 & 0.021 \\
\hline n-3 PUFA & 5.87 & 0.25 & 4.43 & 0.20 & 5.67 & 0.12 & 3.79 & 0.31 & 0.082 & $<0.001$ & 0.349 \\
\hline
\end{tabular}


Table 2 Total fatty acids and fatty acid composition of liver from Alentejana and Barrosã bulls fed high or low silage diets $^{1-3}$ (Continued)

\begin{tabular}{|c|c|c|c|c|c|c|c|c|c|c|c|}
\hline$n-6$ PUFA & $29.75^{a b}$ & 0.77 & $31.80^{b}$ & 0.82 & $30.02^{a b}$ & 0.31 & $27.48^{a}$ & 1.30 & 0.030 & 0.778 & 0.015 \\
\hline n-3 LCPUFA & 4.63 & 0.24 & 3.64 & 0.22 & 4.46 & 0.12 & 3.06 & 0.28 & 0.107 & $<0.001$ & 0.368 \\
\hline n-6 LCPUFA & 13.59 & 0.30 & 14.72 & 0.57 & 13.70 & 0.42 & 12.81 & 0.83 & 0.124 & 0.835 & 0.087 \\
\hline
\end{tabular}

SFA $=$ sum of 14:0, 15:0, 16:0, 17:0, 18:0, 20:0 and 23:0; MUFA = sum of 14:1c9, 16:1c7, 16:1c9, 17:1c9, 18:1c9, 18:1c11, 18:1c12, 18:1c13, and 20:1c11; TFA = sum of 18:1 t6-t8, 18:1 t9, 18:1 t10, 18:1 t11, 18:1 t12, 18:1 t16 + c14 and 18:2c9t11; PUFA = sum of 18:2n-6, 18:3n-3, 20:2n-6, 20:3n-9, 20:3n-6, 20:4n-6, 20:5n-3, 22:4n-6, 22:5n-3 and 22:6n-3.

${ }^{1}$ Means in the same row with different superscripts are significantly different $(P<0.05)$.

${ }^{2}$ Total fatty acids are expressed as $\mathrm{g} / 100 \mathrm{~g}$ liver; fatty acid composition is expressed as mol\% fatty acids.

${ }^{3} \mathrm{HS}$ : high silage; LS: low silage.

${ }^{4}$ Other $=$ sum of $\mathrm{i}-15: 0, \mathrm{a}-15: 0, \mathrm{i}-16: 0, \mathrm{i}-17: 0, \mathrm{a}-17: 0$ and dimethylacetals (16:0 DMA and 18:0 DMA).

was performed in order to assess the distinctive metabolic features of each tissue and to describe the variability of the pooled data into two dimensions (Figure 2A). The score plot of the first two components explains $74.59 \%$ of the total variability, with $48.13 \%$ for $\mathrm{PC} 1$ and $26.46 \%$ for $\mathrm{PC} 2$
(Table 4). The score plot from PCA showed the fatty acids associated into four main clusters. In quadrant $b$ ), a cluster is formed by BCFA ( $a-15: 0, i-15: 0, i-16: 0, i-17: 0)$ and some 18:1 isomers (18:1-t16 and 18:1-c14 co-eluted, and 18:1-t6 to $t 8)$. A second cluster, with a significant contribution to

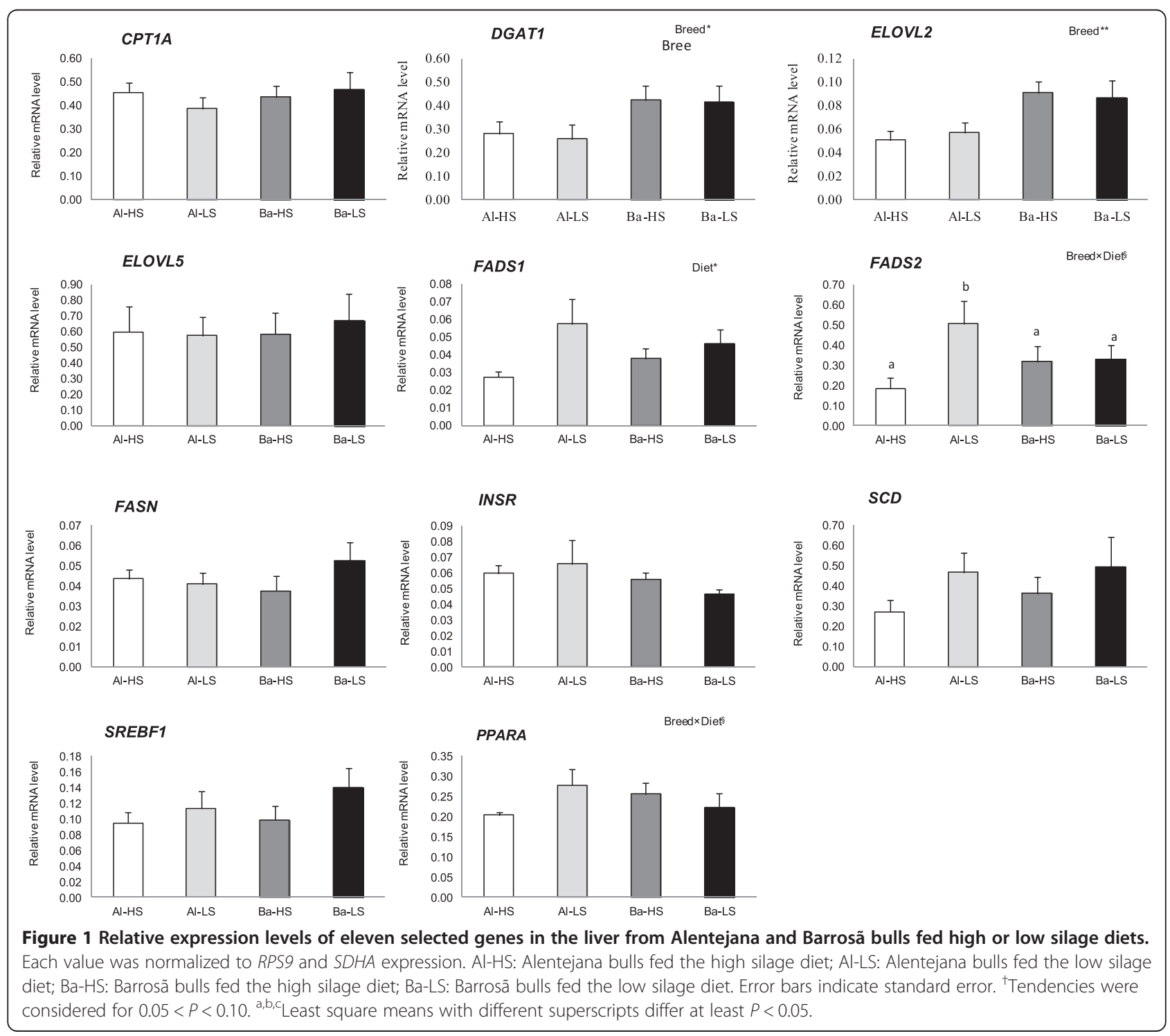


Table 3 Pearson correlation coefficients between the fatty acid composition and the relative gene expression levels in the liver from Alentejana and Barrosã bulls fed high or low silage diets ${ }^{1-4}$

\begin{tabular}{|c|c|c|c|c|c|c|c|c|c|}
\hline & CPT1A & $D G A T 1$ & ELOVL2 & ELOVL5 & FADS1 & FADS2 & FASN & INSR & PPARA \\
\hline $14: 0$ & $0.56^{* * *}$ & & & $0.40^{*}$ & $0.39^{*}$ & $0.34^{*}$ & & $0.32^{*}$ & \\
\hline $14: 1 c 9$ & & & & & & & $0.42^{* *}$ & & \\
\hline $16: 0$ & $0.60^{* * *}$ & & $0.44^{* *}$ & $0.60^{* * *}$ & $0.42^{* *}$ & & & & \\
\hline $16: 1 c 7$ & & & & & $0.48^{* *}$ & $0.44^{* *}$ & & & \\
\hline $16: 1 c 9$ & $0.47^{* *}$ & & $0.37^{*}$ & $0.51^{* * *}$ & $0.38^{*}$ & & & & \\
\hline $17: 0$ & & & $-0.37^{*}$ & & & & & & \\
\hline $17: 1 c 9$ & $0.31^{*}$ & & & $0.39^{*}$ & $0.33^{*}$ & & & & \\
\hline 18:0 & & & & $-0.40^{* *}$ & $-0.41^{* *}$ & & & & \\
\hline $18: 1 t 6 t 8$ & & & & & & $0.32^{*}$ & & & \\
\hline $18: 1$ t9 & & & & & $0.41^{*}$ & $0.40^{*}$ & & & \\
\hline $18: 1$ t10 & & $-0.34^{*}$ & & & & & & & \\
\hline \multicolumn{10}{|l|}{$18: 1 t 11$} \\
\hline \multicolumn{10}{|l|}{$18: 1+12$} \\
\hline $18: 1 c 9$ & $0.42^{* *}$ & & $0.33^{*}$ & $0.50^{* *}$ & $0.38^{*}$ & & & & \\
\hline $18: 1 c 11$ & & & & & $0.51^{* *}$ & $0.40^{*}$ & & & \\
\hline \multicolumn{10}{|l|}{$18: 1 c 12$} \\
\hline $18: 1 \mathrm{cl3}$ & & & & & $0.48^{* *}$ & $0.39^{*}$ & & & \\
\hline \multicolumn{10}{|c|}{$18: 1 t 16 c 14$} \\
\hline $18: 2 n-6$ & & & & $-0.32^{*}$ & $-0.53^{* * *}$ & $-0.52^{* * *}$ & & $-0.33^{*}$ & \\
\hline $20: 0$ & & & & & $0.48^{* *}$ & $0.68^{* * *}$ & & & \\
\hline $18: 3 n-3$ & & & & & $-0.46^{* *}$ & $-0.50^{* *}$ & & & \\
\hline $20: 1 c 11$ & & & & & & $0.38^{*}$ & & $0.32^{*}$ & $0.38^{*}$ \\
\hline $20: 2 n-6$ & $-0.59^{* * *}$ & & & $-0.46^{* *}$ & $-0.34^{*}$ & & & $-0.38^{*}$ & \\
\hline $20: 3 n-9$ & & $0.44^{* *}$ & $0.47^{* *}$ & & & & & & \\
\hline $20: 3 n-6$ & & & & & $0.50^{* *}$ & $0.67^{* * *}$ & & $0.35^{*}$ & \\
\hline $20: 4 n-6$ & & & & & & & & & $0.34^{*}$ \\
\hline \multicolumn{10}{|l|}{$23: 0$} \\
\hline \multicolumn{10}{|l|}{$20: 5 n-3$} \\
\hline $22: 4 n-6$ & $-0.32^{*}$ & & & & $0.72^{* * *}$ & $0.70^{* * *}$ & & & \\
\hline $22: 5 n-3$ & & & & & & & & $0.32^{*}$ & \\
\hline
\end{tabular}

Statistical significance of Pearson correlation coefficients: ${ }^{*}, \mathrm{P}<0.05 ;{ }^{* *}, \mathrm{P}<0.01 ;{ }^{* * *}, \mathrm{P}<0.001$.

${ }^{2}$ Fatty acid contents expressed as $\mathrm{mol} / \mathrm{g}$ liver.

${ }^{3}$ There were no significant correlations between SCD or SREBF1 and individual fatty acids.

${ }^{4}$ There were no significant correlations between 15:0, CLA (c9t11), 22:6n-3 and the mRNA levels of the genes under analysis.

PC1, was formed by 14:0, 16:0, $a-17: 0,18: 1-t 9$ and 18:1- $t 12$. In quadrant $d$ ), a cluster was formed by $c 9 t 11-$ CLA and some MUFA (14:1c9, 16:1c9, 17:1c9, 18:1c11 and 20:1c11). Finally, $18: 2 n-6,18: 3 n-3$ and 20:4n- 6 formed a cluster in quadrant $c$ ), with little or no contribution to PC2 but with significant impact on PC1.

The score plot depicted in Figure 2B showed the location of the four tissues in the multivariate space of the first two PCs. These scores were notably arranged in four clusters, corresponding to the four tissues analysed. The most notable result from this statistical approach is the higher distance between the cluster formed by the liver and the remaining three clusters.

\section{Discussion}

The present study was based on an experiment with two genetically different bovine breeds with distinct maturity rates, Alentejana and Barrosã, fed diets with different silage to concentrate ratio (30/70\% vs. $70 / 30 \%)$. Alentejana and Barrosã breeds, despite being phylogenetically distant [14] share more genetic similarities than the breeds used in previous studies addressing the differences between breeds in fatty acid metabolism, mainly based on the Japanese Black and Holstein breeds [15-17]. We observed in these animals that different fat depots, subcutaneous and mesenteric adipose tissues, had distinct 

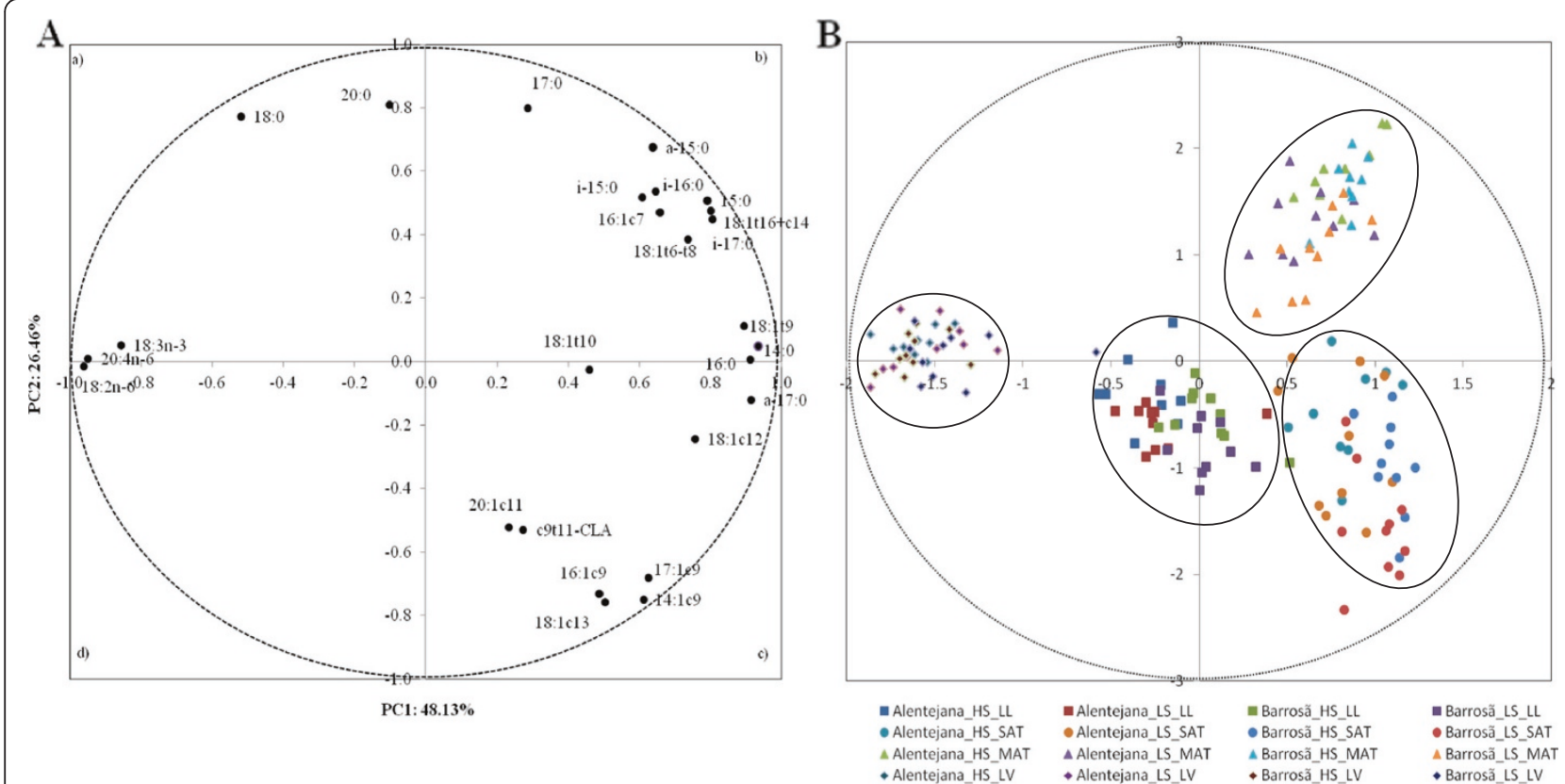

Figure 2 Loading plot of the first and second principal components of the pooled data (A) and component's score vectors (B) for longissimus lumborum muscle, subcutaneous adipose tissue, mesenteric adipose tissue and liver from Alentejana and Barrosã bulls fed high or low silage diets. LL: Iongissimus lumborum muscle; SAT: subcutaneous adipose tissue; MAT: mesenteric adipose tissue; LV: liver; Alentejana -HS: Alentejana bulls fed the high silage diet; Alentejana-LS: Alentejana bulls fed the low silage diet; Barrosã -HS: Barrosã bulls fed the high silage diet; Barrosã -LS: Barrosã bulls fed the low silage diet.

features regarding cellularity and fatty acid composition [12]. Results indicated that genetic background and, to a lesser extent diet composition, determine fat content and composition, pointing out to a differential fat partitioning between subcutaneous and intramuscular fat in Alentejana and Barrosã breeds. In addition, the comparison of fatty acid composition and gene expression levels between the muscle and subcutaneous adipose tissue indicated that these tissues play distinct roles in lipid metabolism, reinforcing the prevailing role of the subcutaneous adipose tissue over intramuscular fat in the de novo fatty acid synthesis (data not shown). In fact, the PCA showed a clear separation of the liver from the remaining tissues (muscle, and subcutaneous and mesenteric adipose tissues), to which contributed the fact that this tissue is particularly rich in $\alpha$-linolenic acid and the products of its desaturation and elongation, the n-3 LC-PUFA. This result suggests that the liver may have an important role in the $\mathrm{n}-3$ LC-PUFA biosynthesis.

The major metabolic fates of long chain fatty acid $\mathrm{CoA}$ in the liver are: i) esterification into triacylglycerols and, to a lesser extent, into phospholipids and cholesterol esters, ii) complete oxidation to $\mathrm{CO}_{2}$ or incomplete oxidation which generates acetate and ketone bodies [1]. De La Torre et al. [18] reported that, once incorporated in vitro into bovine hepatic cells, rumenic and oleic acids are highly catabolised through the $\beta$-oxidation pathway. One possible explanation might be the low efficiency of bovines in secreting fatty acids from the liver [19], thus directing fatty acids preferentially towards the oxidative pathway.

The liver is responsible for the uptake of NEFA and subsequent storage as triacylglycerols or release as VLDL. Hepatic triacylglycerols synthesis is the result of various pathways of lipid metabolism, including fatty acid uptake from plasma, oxidation of fatty acids, de novo synthesis of fatty acids and secretion of triacylglycerols via VLDL $[20,21]$. Apart from hormones, the metabolic regulatory events in the liver are directed by metabolites levels, either in excess (e.g., NEFA) or in shortage (e.g., glucose) [22]. Once in the hepatocytes, catabolism of fatty acids is mostly directed towards the synthesis of ketone bodies for energy utilisation by tissues [4,23]. In spite of the higher insulin levels observed in the bulls fed the low silage diet (data not shown), when compared to those fed the high silage diet, it had no impact on INSR mRNA levels in the liver. Zhang et al. [24] reported low INSR gene expression levels in calf cultured hepatocytes in response to high insulin concentrations. However, it should be noted that in the present study even the highest insulin levels were within physiological levels.

Due to gluconeogenesis in liver, both propionate and lactate can indirectly modulate adipose tissue lipogenesis through increased glucose availability. The glucogenic effect of high-starch diets is often accompanied by an enhanced insulin response [25]. The diacylglycerol acyltransferase 
Table 4 Loadings for the first three principal components ${ }^{1}$

\begin{tabular}{|c|c|c|c|}
\hline Variable & PC1 & PC2 & PC3 \\
\hline $14: 0$ & 0.935 & 0.049 & -0.082 \\
\hline$i-15: 0$ & 0.659 & 0.470 & 0.447 \\
\hline$a-15: 0$ & 0.639 & 0.675 & 0.182 \\
\hline $14: 1<9$ & 0.488 & -0.731 & 0.190 \\
\hline $15: 0$ & 0.791 & 0.507 & 0.034 \\
\hline$i-16: 0$ & 0.645 & 0.537 & 0.391 \\
\hline $16: 0$ & 0.913 & 0.006 & -0.178 \\
\hline$i-17: 0$ & 0.806 & 0.449 & 0.160 \\
\hline $16: 1 c 7$ & 0.608 & 0.520 & 0.161 \\
\hline $16: 1 c 9$ & 0.612 & -0.748 & 0.108 \\
\hline$a-17: 0$ & 0.915 & -0.121 & 0.217 \\
\hline $17: 0$ & 0.287 & 0.800 & -0.201 \\
\hline $17: 1 c 9$ & 0.626 & -0.680 & -0.088 \\
\hline 18:0 & -0.520 & 0.772 & 0.071 \\
\hline $18: 1 t 6-t 8$ & 0.738 & 0.386 & -0.366 \\
\hline $18: 1 t 9$ & 0.895 & 0.112 & -0.198 \\
\hline 18:1 t10 & 0.460 & -0.026 & -0.718 \\
\hline 18:1 t11 & 0.612 & 0.531 & 0.108 \\
\hline $18: 1 c 9$ & 0.763 & -0.560 & -0.063 \\
\hline 18:1c11 & 0.684 & -0.581 & -0.020 \\
\hline $18: 1 c 12$ & 0.757 & -0.243 & -0.096 \\
\hline $18: 1 c 13$ & 0.503 & -0.757 & 0.032 \\
\hline $18: 1 t 16+c 14$ & 0.801 & 0.476 & 0.124 \\
\hline $18: 2 n-6$ & -0.961 & -0.015 & 0.040 \\
\hline $20: 0$ & -0.101 & 0.809 & -0.063 \\
\hline $18: 3 n-3$ & -0.858 & 0.051 & 0.225 \\
\hline 20:1c11 & 0.233 & -0.521 & 0.185 \\
\hline C9t11-CLA & 0.272 & -0.530 & 0.566 \\
\hline $20: 4 n-6$ & -0.951 & 0.009 & 0.134 \\
\hline Proportion of variance (\%) & 48.13 & 26.46 & 0.06 \\
\hline Cumulative variance (\%) & 48.13 & 74.59 & 80.73 \\
\hline
\end{tabular}

${ }^{1}$ PC: principal component.

(DGAT) catalyses the final step in triacylglycerol biosynthesis by converting diacylgycerols and fatty acyl-coenzyme A (CoA) into triacylglycero1s [26]. The DGAT1 gene has also been related to increased hepatic triacylglycerol synthesis in dairy cows [27]. Moreover, mRNA levels of this gene appeared to be susceptible to diet-induced hyperinsulinaemia pre-partum [27]. In the present study, the relative expression levels of DGAT1 was higher in the liver from Barrosã bulls, when compared to Alentejana bulls, although plasma insulin was affected by diet and not by breed as reported in a companion paper [12].

It was suggested that bovine liver converts more efficiently linoleic acid into arachidonic acid than $\alpha$-linolenic acid into n-3 LC-PUFA [22]. In line with this, in the present study the ARA acid percentages were the highest amongst LC-PUFA. The PCA from the fatty acid pooled data showed a clear separation of the tissues analysed, with particular emphasis on the liver. The LA and $\alpha$ linolenic acid, along with ARA acid, were identified as the most contributing for the distancing of the liver cluster from those of the remaining tissues. This observation could be explained by the higher phospholipid/ triacylglycerol ratio in the liver when compared to the other tissues. Given that LA and $\alpha$-linolenic acid originate from diet, this suggests that the liver plays a role in their metabolism, possibly through their desaturation and elongation.

Attending to the putative role of liver in fatty acid elongation and desaturation, as described by others $[4,11]$ and as suggested by the results herein presented for hepatic fatty acid composition, this work was focused on the analysis of gene expression levels of enzymes and transcription factors associated with the $n-3$ and $n-6$ LC-PUFA pathway synthesis. The PPARA, a transcription factor that acts as an important regulator of lipid metabolism and energy homeostasis, plays a key role in the control of the pathways involved in fatty acid uptake, fatty acid binding, fatty acid oxidation, ketogenesis, as well as carnitine synthesis [28]. The fact that the mRNA level of CPT1A, which is controlled by PPARA, was unchanged across experimental groups could indicate that there was no activation of PPARA in the liver. Moreover, activation of PPARA is known to be caused by increased plasma concentrations of NEFA. However, in the present study, there were no significant changes in NEFA plasma levels, which is consistent with the similar PPARA levels across experimental groups.

Polyunsaturated fatty acids that escape $\beta$-oxidation could be converted into longer and/or more unsaturated fatty acids by the elongation-desaturation pathway, LA and $\alpha$-linolenic acid being metabolised, theoretically, into 20:4n-6 and 22:6n-3, respectively [29,30]. In a recent study by Gruffat et al. [4], the conversion of $\alpha$-linolenic acid into longer and/or more unsaturated fatty acids was not detected, yet $13.5 \%$ of LA was converted into ARA. It is widely accepted that members of the n- 6 and $n$ 3 families compete for the elongation-desaturation pathway [31]. Furthermore, the conversion of $\alpha$-linolenic acid and LA into their longer chain homologues is greatly determined by the composition of dietary fats [32]. Harnack et al. [33] suggested that a ratio of $1 / 1$ would lead to the highest formation of $\mathrm{n}-3$ LC-PUFA, given that the conversion of $\mathrm{n}-3$ fatty acids into higher homologues may depend on the ratio of ingested $n-6 / n-3$ fatty acids.

The carnitine palmitoyltransferase (CPT) system is an essential step in the $\beta$-oxidation of fatty acids, including LC-PUFA. Gruffat et al. [4] showed that the rate of 
$\alpha$-linolenic acid oxidation was higher than that of LA, possibly due to higher mitochondrial activity of CPT1A, as suggested by Ide et al. [34]. The positive correlations between CPT1A mRNA levels and the main SFA and MUFA, as well as the negative relationship with some PUFA (20:2n-6 and 22:4n-6) may be attributed to the role of the enzyme in fatty acid $\beta$-oxidation and ketogenesis. The higher SFA and MUFA percentages are a consequence of increased triacylglycerol and NEFA in the hepatic tissue, which would in turn promote fatty acid $\beta$-oxidation in order to prevent their excessive accumulation.

$S R E B F 1$ is a fundamental regulator of fatty acid biosynthesis, suggesting that it could be a key point of control of membrane lipid homeostasis capable of strongly influencing the lipid composition of membranes [35]. The SREBF1 gene regulates a wide array of genes involved in lipid biosynthesis. In the present work, the SREBF1 expression was shown to be correlated with the mRNA levels of FASN, SCD, PPARA and INSR (data not shown). The fatty acid synthase, encoded by FASN, plays a central role in de novo lipogenesis in mammals. However, the FASN mRNA levels were similar across experimental groups and showed no correlation with the main liver fatty acids, thus suggesting no modulation by diet or silage level under these experimental conditions.

The SCD gene encodes for an important enzyme in unsaturated fatty acid synthesis [36]. SCD activity in bovine liver and duodenal mucosal cells has been reported [37-39]. Furthermore, Chung et al. [39] suggested that some portion of the MUFA in adipose tissues may arise from hepatic and mucosal desaturation of dietary SFA. However, in the present work, there was no apparent association between $S C D$ gene expression levels and the desaturation indices. This finding reinforces the concept of a low SCD activity in the liver, which is not to say that there is no desaturation at all. The matter of fact is that hepatic desaturation activity seems to be carried out mainly by the enzymes encoded by FADS1 and FADS2.

The higher expression levels of FADS1 and FADS2 in the low silage than in the high silage fed bulls, particularly Alentejana bulls, is concomitant with the diet effect observed in the percentages of most LC-PUFA and, therefore, with the correlations found. That is, feeding the low silage diet, poorer in 18:2n-6 and $\alpha$-linolenic acid than the high silage diet, promoted the expression of the genes encoding $\Delta 5$ and $\Delta 6$ desaturases in order to incorporate an adequate level of LC-PUFA in membrane phospholipids. The increase in the FADS1 gene expression could have contributed to promote lipid biosynthesis and fatty acid deposition. The FADS1 gene has been considered as one of the rate-limiting enzymes to the endogenous formation of LC-PUFA in humans [40]. In mammals, FADS1 converts dihomo- $\gamma$-linolenic acid $(20: 3 n-6)$ to ARA and eicosatetraenoic acid (20:4n-3) to
EPA with, respectively, LA and $\alpha$-linolenic acid as the initial substrates $[40,41]$.

Liver seems to be highly active in $\alpha$-linolenic acid catabolism [18], thus limiting its subsequent availability for deposition in muscles. There are two basic metabolic fates for $\alpha$-linolenic acid. First, it is subjected to $\beta$ oxidation and extensive carbon recycling. Second, it is converted into longer fatty acids via the elongation and desaturation pathway. Elongation of C18 in the LC-PUFA pathway occurs through elongase enzymes, which have been suggested to have a regulatory role on LC-PUFA synthesis and may be transcribed from one or more genes (ELOVL2 and ELOVL5) [42]. Hepatic LC-PUFA metabolism has been linked to energy balance and physiological state in dairy cattle. Long-chain fatty acyl elongases (ELOVL) are endoplasmatic reticulum membrane-bound proteins responsible for the first regulatory step in the fatty acid elongation pathway (condensation of activated fatty acids with malonyl-CoA), elongating fatty acid that are biosynthesized de novo or supplied by the diet [43]. In mammals, ELOVL2 has greatest activity in the elongation of $\mathrm{C} 20$ and $\mathrm{C} 22$ but low or, in the case of humans, no activity towards C18 PUFA [44]. In contrast, mammalian ELOVL5 is very active towards C18 PUFA but does not appear to have the capacity to elongate beyond C22 [44,45]. Cherfaoui et al. [11] proposed that the limiting step for elongation of $\alpha$-linolenic acid in the muscle tissues is the absence of ELOVL5 protein. Moreover, these authors also suggested that the low levels of DHA in the muscle tissues could be a consequence of its preferential peroxidation or of its preferential uptake by other tissues.

Hepatic ELOVL2 and ELOVL5 are both regulated by SREBP transcription factors in mouse [46]. Nonetheless, in the present study there seemed to be no direct correlation between SREBF1 mRNA levels and the expression of ELOVL2 and ELOVL5 genes, in spite of SREBF1 being correlated with total n-6 PUFA. The higher ELOVL2 gene expression, and thus the higher fatty acid elongase with high activity in the final steps of LC-PUFA biosynthesis, in the Barrosã than in the Alentejana bulls could provide a route to promote EPA and DHA deposition. However, LC-PUFA contents in the liver from the present study were influenced, not by breed, but by diet.

\section{Conclusion}

In summary, the present study suggests that liver has, among the bovine lipogenic tissues, a specific role in lipid metabolism. In addition, the results indicate a breed modulation of hepatic desaturation/elongation of fatty acids, possibly through the differential expression of genes encoding for enzymes involved in the desaturation and elongation pathway. In some cases, the response to varying silage levels was modulated by the genetic background (FADS2 and PPARA), whereas in others (DGAT1 
and ELOVL2) there was a clear breed effect regardless of diet composition. The small differences observed in gene expression levels could have additive effects, which may explain the differences found in the hepatic fatty acid profile, particularly in the LC-PUFA. In summary, the results herein discussed are in line with the previous reports from this experiment, thus stressing the importance of devising custom-made feeding strategies which take into account the genetic background.

\section{Methods}

\section{Animals and experimental diets}

This trial was conducted at the facilities of Unidade de Produção Animal, L-INIA, INIAV (Fonte Boa, Vale de Santarém, Portugal), from January to November 2009. A Animals were handled in accordance with local and national guidelines covering animal experiments, reviewed by the Ethics Commission of CIISA/FMV and approved by the Animal Care Committee of the National Veterinary Authority (Direccão-Geral de Veterinária), following the appropriate European Union guidelines (Directive 86/609/ EEC).

Forty young bulls from Alentejana $(n=20)$ and Barrosã $(n=20)$, were assigned to high or low forage based diets (four experimental groups of 10 animals each). One Alentejana bull from the high silage fed group was later removed from the trial due to a limp. Diets were composed of $30 / 70 \%$ (low silage) and 70/30\% (high silage) of maize silage and concentrate, respectively. The detailed proximate and fatty acid composition of the experimental diets has been published in a previous paper [47]. Briefly, crude fat and starch were higher in the low silage (31.7 and $376 \mathrm{~g} / \mathrm{kg} \mathrm{DM}$, respectively) than in the high silage diet ( 28.7 and $285 \mathrm{~g} / \mathrm{kg}$ DM, respectively). Conversely, the high silage diet had higher crude fibre and NDF contents (198 and $403 \mathrm{~g} / \mathrm{kg} \mathrm{DM}$, respectively) in comparison to the low silage diet (150 and $321 \mathrm{~g} / \mathrm{kg} \mathrm{DM}$, respectively). The low silage diet had lower palmitic (20.2 vs. $24.1 \%)$ and stearic acid (5.1 vs. 9.4\%) percentages than the high silage diet, while the latter showed higher proportions of 20:0 (6.5 vs. 3.7\%), 18:2n-6 (43.9 vs. $40.9 \%$ ) and 18:3n-3 (9.2 vs. 6.0\%). Animals were housed in eight adjacent pens, two pens per breed and diet. The initial age was $331 \pm 32$ days for Alentejana bulls and $267 \pm 10$ days for Barrosã bulls. All animals were slaughtered at 18 months old, which is a common commercial slaughter age for bulls in Portugal. Slaughters were performed at the INIAV experimental abattoir by exsanguination, after stunning with a cartridgefired captive bolt stunner.

\section{Blood sampling}

One week prior to slaughter, blood samples were collected from the tail vein and centrifuged (3000 rpm for 15 minutes at room temperature) to harvest heparinized plasma. Total cholesterol, HDL-cholesterol, LDL-cholesterol, triacylglycerols, aspartate aminotransferase (AST), alanine aminotransferase (ALT) and alkaline phosphatase (ALP) were analysed using diagnostic test kits (Roche Diagnostics, Mannheim, Germany), in a Modular Hitachi Analytical System (Roche Diagnostics). VLDL-cholesterol and total lipids were calculated as described by Friedewald et al. [48] and Covaci et al. [49] formulas, respectively.

Plasma non-esterified fatty acids (NEFA) were quantified using the Free Fatty Acid Quantification Kit (Biovision Inc, Mountain View, CA, USA).

\section{Sample collection}

Immediately after slaughter, liver samples for gene expression analysis were collected, rinsed with sterile RNAse-free water solution, cut into small pieces (thickness of $\sim 0.3 \mathrm{~cm}$ ), stabilised in RNA Later solution (Qiagen, Hilden, Germany) and subsequently stored at $-80^{\circ} \mathrm{C}$. A second sample (approximately $50 \mathrm{~g}$ ) was vacuum-packed and stored at $-20^{\circ} \mathrm{C}$, until lipid extraction and determination of fatty acid composition.

\section{Total lipid content and fatty acid composition}

Liver samples were lyophilised $\left(-60^{\circ} \mathrm{C}\right.$ and $\left.2.0 \mathrm{hPa}\right)$, maintained exsiccated at room temperature and analysed within two weeks. Total lipids were extracted by the method of Folch et al. [50], using dichloromethane and methanol $(2: 1 \mathrm{v} / \mathrm{v})$ instead of chloroform and methanol $(2: 1 \mathrm{v} / \mathrm{v})$, as modified by Carlson [51].

Fatty acids were then converted to methyl esters as described by Raes et al. [52], using sodium methoxide in anhydrous methanol $(0.5 \mathrm{~mol} / \mathrm{L})$ for $30 \mathrm{~min}$, followed by hydrochloric acid in methanol $(1: 1 \mathrm{v} / \mathrm{v})$ for $10 \mathrm{~min}$ at $50^{\circ} \mathrm{C}$. Fatty acid methyl esters (FAME) were extracted twice with $3 \mathrm{~mL}$ of $n$-hexane and pooled extracts were evaporated at $35^{\circ} \mathrm{C}$, under a stream of nitrogen, until a final volume of $2 \mathrm{~mL}$. The resulting FAME were then analysed by GC using a fused-silica capillary column (CP-Sil 88; $100 \mathrm{~m} \times 0.25 \mathrm{~mm}$ i.d., $0.20 \mathrm{~mm}$ film thickness; Chrompack, Varian Inc., Walnut Creek, CA, USA), equipped with a flame ionisation detector, as described by Bessa et al. [9]. The quantification of FAME used nonadecanoic acid (19:0) as the internal standard, added to lipids prior to saponification and methylation. Fatty acid composition was calculated assuming a direct relationship between peak area and fatty acid methyl ester weight.

\section{Total RNA isolation}

Frozen tissue samples were homogenized with an UltraTurrax homogenizer (IKA-Labortechnik, Staufen, Germany). Total RNA was extracted from liver samples using Trizol reagent (Invitrogen, Carlsbad, CA, USA) and purified with the RNeasy Mini Kit (Qiagen Inc), according to the 
manufacturer's protocol. To exclude possible amplification of contaminating genomic DNA, an additional step of DNase digestion was performed with the RNase-free DNase Set (Qiagen Inc.), incubating samples with DNase for $15 \mathrm{~min}$ at room temperature. Total RNA extracts were immediately analysed for quantity (OD260nm) and purity (OD260nm/OD280nm) (NanoDrop ND-2000c, Peqlab $\mathrm{GmbH}$, Erlangen, Germany). RNA aliquots were stored at $-80^{\circ} \mathrm{C}$ and until further analysis.

\section{Synthesis of complementary DNA}

Single-stranded cDNA was synthesised using the High Capacity cDNA Reverse Transcription Kit (Applied Biosystems, Foster City, CA, USA) following the manufacturer's protocol. Each $20 \mu \mathrm{l}$ RT reaction contained $1200 \mathrm{ng}$ of RNA template, $50 \mathrm{nM}$ random RT Primer, $1 \times$ RT buffer, $0.25 \mathrm{mM}$ of each dNTPs, $3.33 \mathrm{U} / \mu \mathrm{l}$ multiscribe reverse transcriptase and $0.25 \mathrm{U} / \mu \mathrm{L}$ RNase inhibitor, at temperatures of $25^{\circ} \mathrm{C}$ for $10 \mathrm{~min}, 37^{\circ} \mathrm{C}$ for $120 \mathrm{~min}$, and $85^{\circ} \mathrm{C}$ for $5 \mathrm{~min} \mathrm{cDNA}$ aliquots were stored at $-20^{\circ} \mathrm{C}$. Total liver RNA was reverse transcribed using a High Capacity cDNA Reverse Transcription Kit (Applied BioSystems) according to manufacturer's instructions.

\section{Primer design and housekeeping gene stability evaluation}

Forward and reverse primers were optimally designed to cover exon-exon junctions to account for alternative splicing when possible (Table 5).

Primer 3 (http://primer3.ut.ee/) and Primer Express software v3.1 (Applied Biosystems, Foster City, CA, USA) were used to design primers for candidate housekeeping (HKG) and target genes, amplicon length was fixed to 70-150 bp. When possible, primer sets were designed to fall across exon-exon junctions. Sequences, amplicon length and reference sequences are summarised

Table 5 Specifications of oligonucleotides used for RT-qPCR ${ }^{1-3}$

\begin{tabular}{|c|c|c|c|c|}
\hline Gene symbol & Full gene name & Acc. Number ${ }^{1}$ & Primer pairs $\left(5^{\prime}-3^{\prime}\right)$ & Amplicon length \\
\hline \multirow[t]{2}{*}{ CPT1A } & carnitine palmitoyltransferase $1 \mathrm{~A}$ & XM_002699420.2 & F: TTCTTCTGGGGTCTACGATTCC & 119 \\
\hline & & & R: GATGTGCTTGCTGTCCCTCAG & \\
\hline \multirow[t]{2}{*}{ DGAT1 } & diacylglycerol O-acyltransferase 1 & NM_174693.2 & F: TTGGCAGGTAAGGCGGC & 99 \\
\hline & & & R: GGGGGCGAAGAGGAAGTAGT & \\
\hline \multirow[t]{2}{*}{ ELOVL2 } & fatty acid elongase 2 & NM_001083517.1 & F: GTCTTCTTACATGATGACGCTGGT & 72 \\
\hline & & & R: ATTGGCTITTCCGGTATGTCTGA & \\
\hline \multirow[t]{2}{*}{ ELOVL5 } & fatty acid elongase 5 & NM_001046597.1 & F: CCCTCTCGGTTGGTTGTATTTC & 127 \\
\hline & & & R: GTGGTCCTITTGGTGCTCTCTC & \\
\hline \multirow[t]{2}{*}{ FADS1 } & fatty acid desaturase 1 & XM_002699285.2 & F: GTGGGTGGACTTGGCCTG & 103 \\
\hline & & & R: TGGGGCTTGTCTTCATGGTC & \\
\hline \multirow[t]{2}{*}{ FADS2 } & fatty acid desaturase 2 & NM_001083444.1 & F: CGGCAAGAAGAAGCTGAAATACCTG & 92 \\
\hline & & & R: CTGCTCATCCCTITGTATTTCCA & \\
\hline \multirow[t]{2}{*}{ FASN } & fatty acid synthase & NM_001012669.1 & F: ATGGCGTTCCACTCCTACTTCA & 137 \\
\hline & & & R: CTCTCCTGCCACTGGGTCTC & \\
\hline \multirow[t]{2}{*}{ INSR } & insulin receptor & XM_002688832.2 & F:ACGCTGGTGGTGATGGAGTT & 133 \\
\hline & & & R: TCTCTGCCGCCATCTGAATC & \\
\hline \multirow[t]{2}{*}{ PPARA } & peroxisome proliferator-activated receptor alpha & NM_001034036.1 & F: CCAACAACAACCCGCCTIT & 125 \\
\hline & & & R: CGTCTTCTCGGCCATACACA & \\
\hline \multirow[t]{2}{*}{ SCD } & stearoyl-CoA desaturase 9 & NM_173959.4 & F: CCATCAACCCCCGAGAGAAT & 76 \\
\hline & & & R: AAGGTGTGGTGGTAGTTGTGGAA & \\
\hline \multirow[t]{2}{*}{ SREBF1C } & sterol regulatory element binding transcription factor 1 & NM_001113302.1 & F: ATCTCTTGGAGCGAGCACTGA & 115 \\
\hline & & & R: AGGTACCCCAGGGCATCTG & \\
\hline \multirow[t]{2}{*}{$\mathrm{RPS}^{3}$} & ribosomal protein $\mathrm{S} 9$ & NM_001101152.1 & F: GAAGGTAATGCCCTGTTGCG & 141 \\
\hline & & & R: CAGGCCCAGCTTGAAGACC & \\
\hline \multirow[t]{2}{*}{$\mathrm{SDHA}^{3}$} & succinate dehydrogenase complex subunit A & NM_174178.2 & F: TGCAGGAAGGCTGTGAGAAGAT & 100 \\
\hline & & & R: GTCTCCACCAGGTCAGTGTTCC & \\
\hline
\end{tabular}

${ }^{1}$ Entrez Gene, National Center for Biotechnology Information (NCBI).

${ }^{2} \mathrm{~F}$ : forward primer and R: reverse primer.

${ }^{3}$ Housekeeping gene. 
in Table 5. Primers were aligned against publicly available databases using BLASTN suite at the National Center of Biotechnology Information.

Prior to RT-qPCR, the various sets of gene-specific primers were tested using a conventional PCR and run in a $2.5 \%$ agarose gel stained with ethidium bromide. Only those primers that did not present primer-dimer and a single band at the expected size in the gel were used for RT-qPCR. The accuracy of a primer pairs was also evaluated by the presence of a unique peak during the dissociation step at the end of RT-qPCR. A set of six candidate housekeeping genes was evaluated using geNorm and NormFinder, as described by Vandesompele et al. [53] and Andersen et al. [54], respectively. The target gene expression levels were calculated using the geometric mean of ribosomal protein S9 (RSP9) and succinate dehydrogenase complex subunit A (SDHA) as a normaliser.

The efficiency of RT-qPCR amplification for each gene was calculated using the standard curve method with five dilutions at each data point along the curve. Dissociation curves were generated at the end of amplification to verify the presence of a single product.

\section{Real time quantitative polymerase chain reaction}

The RT-qPCR was performed with the StepOne Plus ${ }^{\mathrm{Tm}}$ Real-Time PCR System, using the Power SYBR ${ }^{\odot}$ Green master mix (both Applied Biosystems, Foster City, CA, USA). Reaction mixes of $6.25 \mu \mathrm{L}$ Power SYBR Green master mix (Applied Biosystems, Foster City, CA, USA), $1 \mu \mathrm{L}$ of forward and reverse primers $(160 \mathrm{nM})$ and $1 \mu \mathrm{L}$ of diluted cDNA (1:15) template were pipetted into MicroAmp $^{\text {TM }}$ optical 96-Well reaction plates and sealed with optical caps (Applied Biosystems, Foster City, CA, USA). After an initial denaturation at $95^{\circ} \mathrm{C}$ for $10 \mathrm{~min}$, a thermocycling program of $15 \mathrm{~s}$ at $95^{\circ} \mathrm{C}, 60 \mathrm{~s}$ at $60^{\circ} \mathrm{C}$ and $15 \mathrm{~s}$ at $95^{\circ} \mathrm{C}$ was applied (40 cycles). Total fluorescence data and dynamic well factors were continuously collected to generate background-subtracted amplification curves (StepOne ${ }^{\mathrm{TM}}$ Software version 2.2.2, Applied Biosystems, Foster City, CA, USA). PCR analysis of cDNA samples was performed in duplicate, using notranscription and no-template samples as controls. The specificity of the PCR amplification was confirmed by melt curve analysis and agarose gel electrophoresis of PCR products.

\section{Data processing}

The PCR efficiency was calculated for each primer set using the StepOnePlus PCR System software (Applied Biosystems), by amplifying 5-fold serial dilutions of pooled cDNA and run in triplicate. The efficiency curves were used to assess accuracy, linearity and efficiency of the PCR reaction. Accuracy was defined as the $R^{2}$ value of the standard curve, efficiency $E$ was calculated as $E[\%]=(10-1 /$ slope of standard curve -1$) \times 100$. All primer sets exhibited an efficiency ranged between 85 and $110 \%$ and the correlation coefficients were higher than 0.990 .

The relative expression (RE) levels were calculated as a variation of the Livak method [55], corrected for variation in amplification efficiency $\left(\mathrm{E}=10^{-1 / \text { slope }}\right)$, as shown in Eq. 1.

$$
\mathrm{RE}=\mathrm{E}_{\text {endogenous }}{ }^{(\mathrm{CT}, \text { endogenous })} / \mathrm{E}_{\text {target }}{ }^{(\mathrm{CT}, \text { target })}
$$

\section{Statistical analysis}

Statistical analyses were carried out with the Statistical Analysis Systems software package, version 9.2, (SAS Institute, Cary, NC, USA). All statistical analyses were performed based on a $2 \times 2$ factorial arrangement of breed (Alentejana and Barrosã purebreds), diet (high and low silage diets) and their respective interaction. The variances were tested for heteroscedasticity and, for most variables, variance was found to be heterogeneous. Therefore, subsequent data analysis was performed in order to account for heterogeneous variance. The general Satterthwaite approximation was computed in a mixedeffects regression model (PROC MIXED), with breed, diet and their interaction as fixed effects.

The final dataset was analysed using the MIXED procedure of SAS with a model that included breed, diet and their respective interaction as independent variables. Results were expressed as mean \pm standard error. Differences between groups were examined for statistical significance using the PDIFF option (Fisher's test). Differences were significant at $P<0.05$ and tendencies discussed at $P<0.10$. Pearson correlation coefficients were calculated using the CORR procedure of SAS.

A principal component analysis (PCA) was performed using the fatty acid composition of liver, intramuscular fat, mesenteric and subcutaneous adipose tissue. The PRINCOMP procedure was applied to a data set of 156 samples and 30 variables to reduce the dimensionality of the data set and to describe the variability of data in two dimensions. After data normalization, the principal components were considered significant if they contributed more than $5 \%$ for the total variance.

\footnotetext{
Abbreviations

CPT1A: Carnitine palmitoyltransferase 1A; DGAT1: Diacylglycerol

O-acyltransferase 1; DHA: Docosahexaenoic acid; ELOVL2: Fatty acid elongase 2; ELOVL5: Fatty acid elongase 5; EPA: Eicosapentaenoic acid; FADS1:

Fatty acid desaturase 1; FADS2: Fatty acid desaturase 2; FAME: Fatty acid methyl esters; FASN: Fatty acid synthase; HS: High silage; INSR: Insulin receptor; LC-PUFA: Long chain polyunsaturated fatty acids; LL: Longissimus lumborum; LV: Liver; LS: Low silage; NEFA: Non-esterified fatty acids; MAT: Mesenteric adipose tissue; MUFA: Monounsaturated fatty acids; PCA: Principal component analysis; PPARA: Peroxisome proliferator-activated receptor alpha; PUFA: Polyunsaturated fatty acids; RPS9: Ribosomal protein S9;
} 
SAT: Subcutaneous adipose tissue; SFA: Saturated fatty acids; SCD: Stearoyl-CoA desaturase; SDHA: Succinate dehydrogenase complex subunit A; SREBFIC: Sterol regulatory element binding transcription factor 1; TFA: Trans fatty acids.

\section{Competing interests}

The authors declare that they have no competing interests.

\section{Authors' contributions}

ASHC, VMRP and EAR performed the tissue sampling and laboratory work. ASHC was responsible for the statistical analysis. ASHC, RJBB, CMGAF and JAMP were responsible for interpretation of the results and preparation of the manuscript. JAMP and RJBB were responsible for the design of the study. All authors read and approved the findings of the study.

\section{Acknowledgments}

Financial support from Fundação para a Ciência e a Tecnologia grant (PTDC/CVT/2006/66114) and individual fellowships to A.S.H. Costa and V.M.R. Pires (SFRH/BD/2009/61068 and SFRH/BPD/2009/64347, respectively). The authors acknowledge Clínica Médica e Diagnóstico Dr. Joaquim Chaves (Algés, Portugal) for the technical assistance in the serum lipids determination. The authors would like to thank the abattoir staff for their cooperation in tissue sampling and Susana Alves (L-INIA-REQUIMTE) for fatty acid analysis.

\section{Author details}

'CIISA, Faculdade de Medicina Veterinária, Universidade de Lisboa, Av. da Universidade Técnica, Pólo Universitário do Alto da Ajuda, 1300-477 Lisboa, Portugal. ${ }^{2}$ Med.UL, Faculdade de Farmácia, Universidade de Lisboa, Lisboa, Portugal.

Received: 8 May 2013 Accepted: 5 March 2014

Published: 12 March 2014

\section{References}

1. Bauchart D, Gruffat D, Durand D: Lipid absorption and hepatic metabolism in ruminants. P Nutr Soc 1996, 55:39-47.

2. Bell AW: Lipid metabolism in the liver and selected tissues and in the whole body of ruminant animals. Prog Lipid Res 1981, 18:117-164.

3. Emery RS, Liesman JS, Herdt TH: Metabolism of long chain fatty acids by ruminant liver. J Nutr 1992, 122:832-837.

4. Gruffat D, Gobert M, Durand D, Bauchart D: Distinct metabolism of linoleic and linolenic acids in liver and adipose tissues of finishing Normande cull cows. Animal 2011, 5:1090-1098.

5. Prates JAM, Bessa RJB: Trans and n-3 fatty acids. In Handbook of Muscle Foods Analysis. Edited by Nollet LML, Tóldra F. Boca Raton: CRC Press, Taylor and Francis Group; 2009:399-417.

6. Noci F, Monahan FJ, French P, Moloney AP: The fatty acid composition of muscle fat and subcutaneous adipose tissue of pasture-fed beef heifers: influence of the duration of grazing. J Anim Sci 2005, 83:1167-1178.

7. Raes K, Fievez V, Chow TT, Ansorena D, Demeyer D, De Smet S: Effect of diet and dietary fatty acids on the transformation and incorporation of C18 fatty acids in double-muscled Belgian Blue young bulls. J Agric Food Chem 2004, 52:6035-6041.

8. Bauchart D, Gladine C, Gruffat D, Leloutre L, Durand D: Effects of diets supplemented with oil seeds and vitamin $\mathrm{E}$ on specific fatty acids of rectus abdominis muscle in Charolais fattening bulls. In Indicators of Milk and Beef Quality. Edited by Hocquette JF, Gigli S. Rome: EAAP; 2005:431-436.

9. Bessa RJB, Alves SP, Jerónimo E, Alfaia CM, Prates JAM, Santos_Silva J: Effect of lipid supplements on ruminal biohydrogenation intermediates and muscle fatty acids in lambs. Eur J Lipid Sci Technol 2007, 109:868-878.

10. Nakamura MT, Nara TY: Structure, function, and dietary regulation of delat6, delta5, and delta9 desaturases. Annu Rev Nutr 2004, 24:345-376.

11. Chearfaoui M, Durand D, Bonnet M, Cassar-Malek I, Bauchart D, Thomas A, Gruffat D: Expression of enzymes and transcription factors involved in n-3 long chain PUFA biosynthesis in Limousin bull tissues. Lipids 2012, 47:391-401.
12. Costa ASH, Lopes PA, Estevão M, Martins SV, Alves SP, Pinto RMA, Pissarra H, Correia JJ, Pinho M, Fontes CMGA, Prates JAM: Contrasting cellularity and fatty acid composition in Fat depots from alentejana and barrosã bovine breeds Fed high and Low forage diets. Int J Biol Sci 2012, 8:214-227.

13. Costa ASH, Silva MP, Alfaia CPM, Pires VMR, Fontes CMGA, Bessa RJB, Prates JAM: Genetic background and diet impact beef fatty acid composition and stearoyl-CoA desaturase mRNA expression. Lipids 2013, 48:369-381.

14. Beja-Pereira A, Alexandrino P, Bessa I, Carretero Y, Dunner S, Ferrand N, Jordana J, Laloe D, Moazami-Goudarzi K, Sanchez A, Cañon J: Genetic characterization of Southwestern European bovine breeds: a historical and biogeographical reassessment with a set of 16 microsatellites. $J$ Hered 2003, 94:243-250.

15. Taniguchi M, Mannen $H$, Oyama K, Shimakura Y, Oka A, Watanabe $H$, Kojima T, Komatsu M, Harper GS, Tsuji S: Differences in stearoyl-CoA desaturase mRNA levels between Japanese Black and Holstein cattle. Livest Prod Sci 2004, 87:215-220.

16. Wang $\mathrm{YH}$, Bower $\mathrm{NI}$, Reverter $\mathrm{A}$, Tan $\mathrm{SH}$, De Jager N, Wang R, Macwilliam SM, Cafe LM, Greenwood PL, Lenhert SA: Gene expression patterns during intramuscular fat development in cattle. J Anim Sci 2009, 87:119-130

17. Albrecht E, Gotoh T, Ebara F, Xu JX, Viergutz T, Nüernberg G, Maak S, Wegner J: Cellular conditions for intramuscular fat deposition in Japanese Black and Holstein steers. Meat Sci 2011, 89:13-20.

18. De La Torre A, Gruffat D, Chardigny J-M, Sebedio J-L, Durand D, Loreau O, Bauchart D: In vitro metabolism of rumenic acid in bovine liver slices. Reprod Nutr Dev 2005, 45:441-451.

19. Hocquette JF, Bauchart D: Intestinal absorption, blood transport and hepatic and muscle metabolism of fatty acids in preruminant and ruminant animals. Reprod Nutr Dev 1999, 39:27-48.

20. Katoh N: Relevance of apolipoproteins in the development of fatty liver and fatty liver-related peripartum diseases in dairy cows. J Vet Med Sci 2002, 64:293-307.

21. Schlegel G, Ringseis R, Windisch W, Schwartz FJ, Eder K: Effects of a rumen-protected mixture of conjugated linoleic acids on hepatic expression of genes involved in lipid metabolism in dairy cows. J Dairy Sci 2012, 95:3905-3918.

22. Kreipe L, Vernay MCMB, Oppliger A, Wellnitz O, Bruckmaier RM, van Dorland HA: Induced hypoglycemia for 48 hours indicates differential glucose and insulin effects on liver metabolism in dairy cows. J Dairy Sci 2011, 94:5435-5448.

23. Reid JCW, Husbands DR: Oxidative metabolism of long-chain fatty acids in mitochondria from sheep and rat liver. Biochem J 1985, 225:233-237.

24. Zhang Z, Li X, Liu G, Gao L, Guo C, Kong T, Wang H, Gao R, Wang Z, Zhu X: High insulin concentrations repress insulin receptor gene expression in calf hepatocytes cultured in vitro. Cell Physiol Biochem 2011, 27:637-640.

25. Trenkle A: Relation of hormonal variations to nutritional studies and metabolism in ruminants. J Dairy Sci 1978, 61:281-293.

26. Wang $Y, X u H Y, Z$, $h u$ Q: Progress in the study on mammalian diacylgycerol acyltransgerase (DGAT) gene and its biological function. Hereditas 2007, 29:1167-1172

27. Loor JJ, Dann HM, Guretzky NAJ, Everts RE, Oliveira R, Green CA, Litherland NB, Rodriguez-Zas SL, Lewin HA, Drackley JK: Plane of nutrition prepartum alters hepatic gene expression and function in dairy cows as assessed by longitudinal transcript and metabolic profiling. Physiol Genomics 2006, 27:29-41.

28. Desvergne B, Wahli W: Peroxisome proliferator-activated receptors: nuclear control of metabolism. Endocr Rev 1999, 20:649-688.

29. Sprecher H: Metabolism of highly unsaturated $\mathrm{n}-3$ and $\mathrm{n}-6$ fatty acids. Biochimica Et Biophysica Acta 2000, 1486:219-231.

30. Burdge GC, Calder PC: Conversion of a-linoleic acid into longer-chain polyunsaturated fatty acids in human adults. Reprod Nutr Dev 2005, 24:469-482.

31. Sprecher H: Biochemistry of essential fatty acids. Prog Lipid Res 1981, 20:13-22.

32. Christiansen EN, Lund JS, Rortveit T, Rustan AC: Effect of dietary n-3 and $\mathrm{n}-6$ fatty acids on fatty acid desaturation in rat liver. Biochim Biophys Acta 1991, 1082:57-62 
33. Harnack K, Andersen G, Somoza V: Quantification of alpha-linolenic acid elongation to eicospentaenoic and docosahexaenoic acid as affected by the ratio of n-6/n-3 fatty acids. Nutr Metab 2009, 6:8

34. Ide T, Murata M, Sugano M: Stimulation of the activities of hepatic fatty acid oxidation enzymes by dietary fat rich in a-linolelic acid in rats. J Lipid Res 1996, 37:448-463.

35. Hagen RM, Rodriguez-Cuenca S, Vidal-Puig A: An allostatic control of membrane lipid composition by SREBP1. FEBS Lett 2010, 584:2689-2698.

36. Loor JJ, Everts RE, Bionaz M, Dann HM, Morin DE, Oliveira R, Rodriguez-Zas SL, Drackley JK, Lewin HÁ: Nutrition-induced ketosis alters metabolic and signaling gene networks in liver of periparturient dairy cows. Physiol Genomics 2007, 32:105-116.

37. Chang JHP, Lunt DK, Smith SB: Fatty acid composition and fatty acid elongase and stearoyl-CoA desaturase activities in tissues of steers fed high oleate sunflower seed. J Nutr 1992, 122:2074-2080

38. Archibeque SL, Lunt DK, Tume RK, Smith SB: Fatty acid indices of stearoyl Co-A desaturase activity do not reflect actual stearoyl Co-A desaturase enzyme activity in adipose tissues of beef steers finished with corn-, flaxseed-, or sorghum-based diets. J Anim Sci 2005, 83:1153-1166.

39. Chung KY, Lunt DK, Kawachi $H$, Yano H, Smith SB: Lipogenesis and stearoyl-CoA desaturase gene expression and enzyme activity in adipose tissue of short- and long-fed Angus and Wagyu steers fed corn- or hay-based diets. J Anim Sci 2007, 85:380-387.

40. Lattka E, Illig T, Koletzko B, Heinrich J: Genetic variants of the FADS1 FADS2 gene cluster as related to essential fatty acid metabolism. Curr Opin Lipidol 2010, 21:64-69.

41. Schaeffer LR: Strategy for applying genome-wide selection in dairy cattle. J Anim Breed Genet 2006, 123:218-223.

42. Jakobsson R, Westerberg A, Jacobsson A: Fatty acid elongases in mammals: Their regulation and roles in metabolism. Prog Lipid Res 2006, 45:237-249.

43. Morais S, Monroig O, Zheng X, Leaver MJ, Tocher DR: Highly unsaturated fatty acid synthesis in Atlantic salmon: characterization of ELOVL5- and ELOVL2-like elongases. Mar Biotechnol 2009, 11:627-639.

44. Leonard AE, Pereira SL, Sprecher H, Huang Y-S: Elongation of long-chain fatty acids. Prog Lipid Res 2004, 43:36-54.

45. Inagaki K, Aki T, Fukuda Y, Kawamoto S, Shigeta S, Ono K, Suzuki O: Identification and expression of a rat fatty acid elongase involved in the biosynthesis of C18 fatty acids. Biosci Biotechnol Biochem 2002, 66:613-621

46. Horton JD, Shah NA, Warrington JA, Anderson NN, Park SW, Brown MS, Goldstein JL: Combined analysis of oligonucleotide microarray data from transgenic and knockout mice identifies direct SREBP target genes. Proc Natl Acad Sci USA 2003, 100:12027-12032.

47. Martins AP, Lopes PA, Costa ASH, Martins SV, Santos NC, Prates JAM, Moura TF, Soveral G: Differential mesenteric fat deposition in bovines fed on silage or concentrate is independent of glycerol membrane permeability. Animal 2011, 5:1949-1956.

48. Friedewald WT, Levy RI, Fredrickson DS: Estimation of the concentration of low- density lipoprotein cholesterol in plasma, without use of the preparative ultracentrifuge. Clin Chem 1972, 18:499-502.

49. Covaci A, Voorspoels S, Thomsen C, VanBavel B, Neels H: Evaluation of total lipids using enzymatic methods for the normalization of persistent organic pollutant levels in serum. Sci Total Environ 2006, 366:361-366

50. Folch J, Lees M, Stanley GHS: A simple method for the isolation and purification of total lipides from animal tissues. J Biol Chem 1957, 226:497-509.

51. Carlson LA: Extraction of lipids from human whole serum and lipoproteins and from rat liver tissue with methylene chloride-methanol: A comparison with extraction with chloroform-methanol. Clin Chim Acta 1985, 149:89-93.

52. Raes K, De Smet S, Demeyer D: Effect of double-muscling in Belgian Blue young bulls on the intramuscular fatty acid composition with emphasis on conjugated linoleic acid and polyunsaturated fatty acids. Anim Sci 2001, 73:253-260.

53. Vandesompele J, De Preter K, Pattyn F, Poppe B, Van Roy N, De Paepe A Speleman F: Accurate normalization of real-time quantitative RT-PCR data by geometric averaging of multiple internal control genes. Genome Biol 2002, 3:7.
54. Andersen $\mathrm{CL}$, Jensen $\mathrm{J}$, Orntoft TF: Normalization of real-time quantitative reverse transcription-PCR data: A model-based variance estimation approach to identify genes suited for normalization, applied to bladder and colon cancer data sets. Cancer Res 2004, 64:5245-5250.

55. Livak KJ, Schmittgen TD: Analysis of relative gene expression data using real-time quantitative PCR and the 2(-Delta C(T)) Method. Methods 2001 25:402-408.

doi:10.1186/1746-6148-10-65

Cite this article as: da Costa et al:: Is hepatic lipid metabolism of beef cattle influenced by breed and dietary silage level? BMC Veterinary Research 2014 10:65.

\section{Submit your next manuscript to BioMed Central and take full advantage of:}

- Convenient online submission

- Thorough peer review

- No space constraints or color figure charges

- Immediate publication on acceptance

- Inclusion in PubMed, CAS, Scopus and Google Scholar

- Research which is freely available for redistribution

Submit your manuscript at www.biomedcentral.com/submit
C) Biomed Central 